million acres, or about 7 per cent of the former area of the country, is now about to be advanced a further stage towards completion. It is announced from The Hague that a sum of two million florins (about $£ 154,000$ ) has just been voted in the national budget for continuing the work of reclaiming the Zuider Zee, and it is likely that additional grants will follow shortly. The scheme was described in detail in an article which appeared in the issue of NATure of September 21, 1929 (p. 446), at which date the first section, the North-west Polder of 50,000 acres, was at the point of complete enclosure. This polder was pumped clear of water in the following year, and it has since been brought into cultivation with satisfactory results. It is now intended to proceed with the reclamation of the second section, the Northeast Polder, containing 117,000 acres. The cost is estimated at about $£ 9,600,000$ and the work will take about five years, providing work for about 5,500 men. Another ten years will be required to bring the saltsaturated soil into a completely effective state of productivity. The outer dyke, or embankment, enclosing the polder, starts from Lemmer in Friesland and follows a widely sweeping curve, first westerly, then southerly and finally easterly to a point on the coast-line north of Kampen. It will be 35 miles long, and for a great part of that distance will run parallel to a new canal. The reclaimed area will lie at two different levels, one about 13 feet and the other about 18 feet below water-level at Amsterdam, and three large pumping stations are to be provided to deal with the fresh-water drainage after completion.

\section{Oldbury Hill, Ightham}

As attempt to save Oldbury Hill, Ightham, from development for building purposes, is one which has a strong claim on the practical support of all archæologists. This Kentish woodland plateau, lying between Sevenoaks and Ightham, is for British archæology historic ground. At its summit is a prehistoric fortress, which is dated at about 200 B.c.; but its chief interest lies in its evidence of prehistoric man of a far earlier period. It is a part of the country over which Benjamin Harrison of Ightham, the apostle of the eolith, had his hunting ground; and through him it is linked with the great names in the study of British archæology-Sir Joseph Prestwich, Sir John Evans, Lord Avebury, and many others. The fortress itself is scheduled for protection under the Office of Works, and in the event of building development, provision for access will have to be made in the inevitable encroachment; but the character of the site with its associations and its wide views over pastoral lands, which preserve the meaning and purpose of its fortification, will be irretrievably lost. The extent of the estate now offered for sale is about 157 acres, and the owner, who is not in a position to present the site to the public, has fixed at the lowest possible figure the price at which he would be prepared to effect a transfer to the National Trust. This body, however, has no funds with which to purchase; but an effort is being made, up to the present with indifferent success, to organise a local fund. The importance to science of the high terrace gravels in which the evidence has been found for what is claimed to be the earliest traces of man's handiwork is obvious; the fact that that evidence has not been accepted universally makes it all the more important that such a site as Oldbury Hill should be preserved for the inspection and investigation of later generations.

\section{History of the English Parliament}

IT is announced that H.M. Stationery Office will publish at an early date a volume, the first to be issued, of the "History of Parliament", which has been in course of preparation for some time under the supervision of a committee presided over by the Marquess of Salisbury. This undertaking, which will cover the whole period of parliamentary government from its inception in 1264 up to 1918 , is an outcome of the report of a committee which was appointed in 1929 with Colonel J. Wedgwood as its chairman, to examine the material available for a record of the personnel and polities of the members of the House of Commons. A joint meeting of both Houses decided that the scope of the work should be extended so as to make it as complete a record as possible of "the people in Parliament-their ideas, standing, and politics-and to trace the gradual growth of Parliamentary representation and government". The work will fall into seventeen or eighteen periods, the material for each being grouped into two or three volumes. This material will comprise biographies of members of the Commons, complete lists of the members of both Houses with identifications, a preface to each Parliament with a commentary on its composition and the work done, and conclusions, appendixes, documents, etc. It is expected that the "History" will consist of some forty volumes, and that it will be completed in about thirty years; but as the price-possibly not more than $£ 22 s$. per volume-will cover cost of printing and publica. tion only, the rate of production will depend upon the funds available for the collection and preparation of the material. For the first volume to be issued, covering the period 1439-1509, Colonel Wedgwood, it is understood, has been largely responsible. Subscribers to the whole work will be charged threequarters of the published price, a first payment of $\mathfrak{f 1 0}$ being required with the undertaking to subscribe, against which the cost will be charged as each volume is issued.

\section{Higher Paraffins as Liquid Fuel}

Higher paraffins such as butane are easily liquefied at air temperature, and give a concentrated and easily vaporised liquid fuel-the most concentrated fuel commercially available having a heating value of 21,000 B.T.U. per lb. In several countries this product has been recovered from natural sources or oil refineries, and distributed in cylinders. In the United States this 'bottled gas' has become extens. ively used in rural areas, and the development of coal hydrogenation in England has led to its being marketed now under the name of 'Calorgas'. 